\title{
Investigating the Well-being of Adolescents Enrolled in Religious Vocational High Schools through Self-perception Figures
}

\author{
Müge Yukay Yüksel ${ }^{\mathrm{a}}$ \\ Hacer Yildırım Kurtuluş \\ Ayşe Ezgi Damar
}

\begin{abstract}
Similar to other psychosocial periods, adolescence requires adaptation by individuals in order to pass through successfully. During adolescence individuals might encounter many personal, social, occupational and economic issues. Therefore it is important for them to maintain a positive sense of self, be uniquely individualized by maintaining their psychological well-being, and develop their own self-perceptions through greater self-awareness. The present study aims to investigate the psychological well-being of ninth-grade adolescent students enrolled in religious vocational high schools through the lens of their self-perceptions depending on several variables and further to shed light on similar studies. Participants in this study comprised 160 students aged 14 from different socioeconomic backgrounds. These participating students attend Kadıköy Male Religious Vocational High School (Boarding) and Sultanbeyli Female Religious Vocational High School in Istanbul. In this study, the Psychological Well-being Scale and the picture drawing technique were used for data collection. Results revealed that though students' levels of psychological well-being do not vary significantly depending on the self-perception figures drawn by them, there are significant differences depending on gender, their perceived socioeconomic level and whether they are boarding at the school.
\end{abstract}

Keywords: Psychological Well-being • Adolescence • Self-perception

a Corresponding author

Müge Yukay Yüksel, Ph.D., Department of Guidance and Psychological Counseling, Faculty of Education, Marmara University, İstanbul, Turkey

Research areas: Projective testing; Learning disabilities; Guidance and counseling in preschool education; Guidance and counseling in special education; Elderly and old age counseling

Email: muge.yuksel@marmara.edu.tr

b Hacer Yıldırım Kurtuluş, Psychological Counsellor, Kadıköy Boys' Anatolian Religious High School, İstanbul, Turkey Email: haceryildirim91@gmail.com

c Ayșe Ezgi Damar, Psychological Counsellor, Sultanbeyli Girls' Anatolian Religious High School, İstanbul, Turkey Email: ezgi-_-damar@hotmail.com 
Adolescence occurs between childhood and adulthood and embodies physical and emotional changes, developments, and growth of an individual. Following this period, the adolescent should have a firm identity, recognize that he/she is unique and prepare the ground to create self-perception by being aware of his/ her ego (Haran, 1992).

The self can be defined as self-perception and self-assessment methods, whereas Carl Jung pointed out that psychological well-being is actualized by being a "self" and a "whole person". In other words, psychological health occurs only when we face and are aware of unwanted or dark features of ourselves and not when we escape from these realities (Corey, 2005). In his book The Undiscovered Self, Jung stated: "As we get to know ourselves or in other words, as we explore our own soul, we are faced with our instincts and their world filled with images shed light on the forces which we rarely notice as long as everything goes well as they sleep in the depths of our souls. They are terrific potential and influential forces. Whether these forces, related images and thoughts will lead us to a positive and constructive way or to a disaster depends fully on the preparedness of the conscious mind and its approach.” (Çınar, 2011).

Drawing a boundary between personality and the self is difficult because though the self and the personality are intertwined in terms of development and structure, the self has characteristics that differ from those of the personality. These characteristics refer to awareness of one's own personality and its description as well as the ability of self-judgment. The self is the individual's subjective side thus the adolescent is in constant search of his or her own self (Köknel, 1982).

Childhood is an indubitably critical period with regard to the formation of the personality within the arguments of Freud. During childhood, the way the mother and the child interact and the quality of this relationship are especially decisive in the formation of the child's personality development; ways of perceiving themselves (self-perception), their relationships, and their environment; and psychological well-being when they reach adulthood (Halisdemir, 2013). Though we often evaluate personality traits of adults who have passed through adolescence, we should focus on their experiences and, family relationships, during childhood and the effects of these factors on the "youth." 
The basic configurations during adolescence are centered on personality development. It is known that adolescents exert great effort toward the development of self. Though some people pass through adolescence comfortably and securely, some find it challenging and troublesome (Demir, Dereboy, \& Dereboy, 2009). Similarly, Erickson (1968) argues that the development of self is a prominent feature of adolescence and that the developmental task of this period is identity seek (Erickson, 1968). Adolescents in such a pursuit start to question their existing values and the meaning of life. They may encounter problems in gaining psychological independence, finding new sources to guide them, and finding acceptance. These individuals are inclined to adapt to find a way through the complicated task of becoming an independent individual and being accepted in society. Common problems during adolescence include conflicts with parents, failure at school, and difficulties in relationships between themselves and people of the opposite sex (Haran, 1992). Furthermore, social skills develop during this period, in which anxieties and conflicts are frequently observed. In 1904, G. Stanley Hall conducted the first scientific studies pertaining to this period and defined adolescence as a period of "storm and stress." It is suggested that as adolescents deal with their problems in a constructive way, they can display healthy identity development (Hamurcu, 2011).

These discussions on well-being have continued since Aristotle, who stated that there is "well-being" (eudemonism) at the very peak of the things that can be succeeded through human behaviors. Later, Bradburn (1969) approached Aristotle's definition of well-being differently, considering it as happiness, which he identified as the result of life satisfaction (as cited in Yilmaz, 2013).

According to Myers, Sweneey, and Witner (2004), well-being is a way of life that embodies happiness, and is related to being healthy at the maximum desired level, being directed to do good deeds, being a self-sufficient person maintaining the goal of self-realization, aiming to actively achieve this goal, and being fully functional within society.

Various researchers have attempted to explain well-being however Ryff's (1989) definition of well-being and the psychological well-being model are important and form the theoretical base of the issue. From Ryff's viewpoint, well-being is not synonymous with happiness; rather, it should be approached as a concept referring to the development of a person's own maximum potential and the 
actualization of him/herself. She defined psychological well-being as positive psychological functionality and investigated this concept under six dimensions: self-acceptance, positive relationships with others, autonomy, environmental control, life goals, and personal development (Kuyumcu, 2012). Ryff's versatile presentation of well-being is important because her self-acceptance component refers to an individual's positive assessment of his/her past life or of him/herself, the recognition and acceptance of various aspects of the self, and creating his/her self-perception. The dimension of positive relationships with others refers to a tendency towards quality, empathy, love, and friendship in his/her relationships with other people. In addition autonomy is related to reaching a level at which the individual makes decisions depending on his/her own selfjudgment. Environmental control describes people's capacity to effectively manage their life circumstances. Life goals are the individuals' belief in the meaningfulness and purposefulness of their lives, and personal development is described as a feeling of continued development while gaining new experiences and achieving a sense of realizing their potential (Cenkseven, 2004).

Reviewing the relevant literature on psychological well-being reveals that in many studies, females have clearly gained higher scores than males with regard to the "positive relationships with others" and "personal development" components (Cooper, Okamura, \& McNeil, 1995; Ryff, 1989, 1991, 1995; Ryff, Lee, Essex, \& Schmutte, 1994). For instance, Cenkseven (2004) indicated that gender is one of the predictors of psychological well-being and added that the scores of girls are higher than those of adolescent boys in terms of the "positive relationships with others," "life goals," "self-acceptance," and "personal development" sub-dimensions.

Thus far related literature has concentrated on investigating psychological well-being depending on variables such as physical health, personality, family support, marital status, social support, social skills, age, gender, educational background and academic achievement, income level, self-esteem, and emotional intelligence (Cenkseven, 2004; Gülaçt1, 2009; Gürel, 2009; Sayg1n, 2008; Timur, 2008). However, there are no previous studies exploring adolescents' specific psychological well-being or self-perception.

For adolescents to have psychological well-being, they require assistance to pass healthily through this self-development stage and realize themselves. 
Therefore, this study aims to investigate adolescents' psychological well-being depending on the self-perception figures drawn by them.

Thus, the following sub-aims have been formulated for the present study:

- Does adolescents' level of well-being differ depending on the gender variable?

- Does adolescents' level of well-being differ depending on their socioeconomic level?

- Does adolescents' level of well-being differ depending on whether they are boarding at school?

- Does adolescents' level of well-being differ depending on their positive / negative self-perception figures?

\section{Method}

In this section, the research model, participant details, data collection instruments and information about the data analysis are provided.

\section{Research Model}

In this study, the investigation of ninth- grade male and female students' psychological well-being through the self-perception figures they draw is based on a screening research model that mixes qualitative and quantitative research methods. Screening models are research approaches aiming to describe an event from the past or present as it exists in the mind of the participant (Karasar, 2007). On the other hand, a mixed method approach involves the collection of both qualitative and quantitative data related to the same main phenomena in a single study or in a number of studies as well as the analysis of the data and their interpretation (Leech \& Onwuegbuzie, 2007). 


\section{Participants}

The participants in this study were 160 ninth-grade students in Istanbul, 80 of whom attend the Sultanbeyli Female Religious Vocational High School, whereas the remaining 80 are boarding students attending the Kadıköy Male Religious Vocational High School.

\section{Data Collection Instruments}

The qualitative data were collected using the Psychological Well-being Scale, and the qualitative data were obtained via the picture drawing technique. Following the Psychological Well-being Scale, students were given a blank size A4 paper and were asked to draw a symbol, figure, or shape that they believe reflects their true selves. They were also asked to write on the back of this paper one sentence about what they drew.

Psychological Well-being Scale: The Psychological Well-being Scale was developed by Ryff (1989) as a self-reporting scale that aims to assess psychological well-being. The scale was developed after a piloting session with 321 people. The scale contains 84 items and 6 factors in the form of a Likerttype scale: positive relationships with others, autonomy, environmental control, personal development, life goals, and self-acceptance. Each factor is comprised of 14 items. A total score can be obtained from the Scale of Psychological Well-being, whereas sub-factors can be scored separately. The highest score that can be obtained in the scale is 504 , and the lowest score is 84 . High scores in the scale mean that psychological well-being is highly present. The internal consistency coefficients (Cronbach's alpha) for the factors were as follows: positive relationships with others, .91; autonomy, .86; environmental control, .90; personal development, .87; life goals, .90; and self-acceptance, .93. The test-retest reliability coefficients are between .81 and .88 . The adaptation study of the scale into Turkish was first carried out by Cenkseven (2004).

The reliability study was conducted with the involvement of 475 university students. The internal consistency coefficients of the scale (Cronbach's alpha) were as follows: positive relationships with others, .83; autonomy, .78; environmental control, .77; personal development, .74; life goals, .76; self- 
acceptance, .79. The total internal consistency coefficient of the Psychological Well-being Scale was found to be .93. The correlation coefficients for the testretest reliability were found as follows: positive relationships with others, .74; autonomy, .77; environmental control, .77; personal development, .74; life goal, .75; self-acceptance, .76 . In addition, the test-retest correlation coefficient for the total score was determined to be .84 . The adaptability of the study into Turkish was conducted by Cirhinlioğlu (2006).

The scale was administered to a total of 515 randomly selected first- and fourthgrade student volunteers at Cumhuriyet University. Correlation coefficients in the item-total correlations were between .14 and .68. The internal consistency coefficient (Cronbach's alpha) was found to be .91, and the split-half reliability was found to be .86 . The internal consistency coefficients of the subscales (Cronbach's alpha) were as follows: positive relationships with others, .77; autonomy, .73; environmental control, .83; personal development, .74; life goals, .75; and self-acceptance, .86 . The results of factor analysis are parallel to Ryff's (1989) findings about the original scale.

\section{Data Collection}

The quantitative data of the study were collected from voluntary participants using the above scales, whereas the qualitative data were gathered via the picture drawing technique. In this technique, students were asked to express their own self-perception by drawing a symbol, image, or object and explaining their drawing in one sentence. The data collection application process took 45 minutes and was conducted by researchers in the participants' classrooms; only voluntary participants were selected. In addition to descriptive statistics, $t$-tests were used to analyze the data obtained during the data collection phase.

\section{Findings}

The findings are presented below in an effort to an answer the question "Does adolescents' level of well-being differ depending on gender, perceived socioeconomic level, whether they are boarding at the school, and positive or negative self-perception?"The findings pertaining to this question are illustrated in Tables 1, 2, 3, and 4. 
Table 1

Investigation of the Psychological Well-being Scale Scores Depending on the Gender Variable

\begin{tabular}{|c|c|c|c|c|c|c|c|c|}
\hline \multirow{2}{*}{ Score } & \multirow{2}{*}{ Groups } & \multirow{2}{*}{$N$} & \multirow{2}{*}{$\bar{X}$} & \multirow{2}{*}{$S S$} & \multirow{2}{*}{$\mathrm{Sh}_{\overline{\mathrm{x}}}$} & \multicolumn{3}{|c|}{$t$ Test } \\
\hline & & & & & & $t$ & $S d$ & $p$ \\
\hline \multirow{2}{*}{ Psychological well-being } & Male & 80 & 310.91 & 37.27 & 4.16 & \multirow{2}{*}{-4.122} & \multirow{2}{*}{5.89} & \multirow{2}{*}{.000} \\
\hline & Female & 80 & 335.21 & 37.28 & 4.16 & & & \\
\hline
\end{tabular}

As can be seen in Table 1, the difference in the arithmetic means of the groups was found to be significant $(t=-4.122 ; p<.001)$ based on the independent samples $t$-test that was applied to reveal whether the scores of participants vary significantly depending on the gender variable. This significance was determined to be in favor of the female students.

Table 2

Investigation of the Psychological Well-being Scale Scores Depending on the Perceived Socioeconomic Level

\begin{tabular}{llllllllll}
\hline \multirow{2}{*}{ Score } & \multirow{2}{*}{ Groups } & \multirow{2}{*}{$N$} & $\bar{X}$ & $S S$ & $S_{h_{\bar{x}}}$ & \multicolumn{4}{c}{$t$ Test } \\
\hline \multirow{2}{*}{ Psychological well-being } & Low & 80 & 335.21 & 37.28 & 4.16 & \multirow{2}{*}{$S d$} & $p$ \\
& High & 80 & 310.91 & 37.27 & 4.16 & -4.122 & \multirow{2}{*}{5.89} & \multirow{2}{*}{.000} \\
\hline
\end{tabular}

As can be understood from Table 2, the difference in the groups' arithmetic means was found to be significant $(t=-4.122 ; p<.001)$ based on the results of the independent samples $t$-test that was used to show whether the scores of participants vary significantly depending on the perceived socioeconomic level variable. This significance was found to be in favor of the students with low socioeconomic levels.

\begin{tabular}{|c|c|c|c|c|c|c|c|c|}
\hline \multicolumn{9}{|l|}{$\begin{array}{l}\text { Table } 3 \\
\text { Investigation of the Psyc }\end{array}$} \\
\hline \multirow{2}{*}{ Score } & \multirow{2}{*}{ Groups } & \multirow{2}{*}{$N$} & \multirow{2}{*}{$\bar{X}$} & \multirow{2}{*}{$S S$} & \multirow{2}{*}{$\mathrm{Sh}_{\overline{\mathrm{x}}}$} & \multicolumn{3}{|c|}{$t$ Test } \\
\hline & & & & & & $t$ & $S d$ & $p$ \\
\hline \multirow{2}{*}{ Psychological well-being } & Boarding & 80 & 310.91 & 37.27 & 4.16 & \multirow{2}{*}{-4.122} & \multirow{2}{*}{5.89} & \multirow{2}{*}{0.000} \\
\hline & Not Boarding & 80 & 335.21 & 37.28 & 4.16 & & & \\
\hline
\end{tabular}

Table 3 presents the results of the independent samples $t$-test that was applied to investigate whether participants' scores vary depending on whether they are boarding at the school. According to the table, the difference in the arithmetic means of the groups was found to be significant $(t=-4.122 ; p<.001)$; further, this difference was in favor of the students who do not stay in the dormitories. 
Table 4

Investigation of Variation in the Psychological Well-being Scale Scores Depending on the Self-perception Figures Drawn by the Participants

\begin{tabular}{|c|c|c|c|c|c|c|c|c|}
\hline \multirow{2}{*}{ Score } & \multirow{2}{*}{ Groups } & \multirow{2}{*}{$N$} & \multirow{2}{*}{$\bar{X}$} & \multirow{2}{*}{$S S$} & \multirow{2}{*}{$\mathrm{Sh}_{\overline{\mathrm{X}}}$} & \multicolumn{3}{|c|}{$t$ Test } \\
\hline & & & & & & $t$ & $S d$ & $p$ \\
\hline \multirow{2}{*}{ Psychological well-being } & Positive & 111 & 319.08 & 37.89 & 3.59 & \multirow{2}{*}{-1.901} & \multirow{2}{*}{6.83} & \multirow{2}{*}{0.061} \\
\hline & Negative & 49 & 332.21 & 40.71 & 5.81 & & & \\
\hline
\end{tabular}

Table 4 illustrates the results of the independent samples $t$-test that was applied to show whether the scores of participants vary significantly depending on the self-perception figures that they drew. The difference in the groups' arithmetic means was not significant $(t=-1.301 ; p>.05)$.

\section{Qualitative Findings}

To analyze the qualitative data of the study, content analysis was employed. In content analysis, themes and categories are formed based on the obtained qualitative data with the goal of identifying and discussion concepts and relationships that can justify the data. As Yıldırım and Şimşek (2013) stated, the data summarized and interpreted descriptively are subjected to a deeper analysis process by means of content analysis, and thus, this analysis method reveals concepts and themes that cannot be noticed using a descriptive approach. For analysis of the qualitative data, adolescents' statements about the pictures they drew to explain their self-perception were examined. The content in these statements was interpreted based on every single word. The following six themes appeared as a result of interpreting the words in their statements: emotions, concepts, future plans, religious life, interests, and personality. Related categories were formed for each theme. 


\begin{tabular}{|c|c|c|}
\hline $\begin{array}{l}\text { Table } 5 \\
\text { Investigation of Adolescents' Statements about the Pictures } \\
\text { Gender Variable }\end{array}$ & io & in on the \\
\hline Adolescent Boys' Pictures Symbolizing Self-perception & $f$ & $\%$ \\
\hline Emotions (positive) & & \\
\hline Happiness (Smiley) & 2 & $1.25 \%$ \\
\hline Sacrifice (Dying for others) & 1 & $0.6 \%$ \\
\hline Emotions (negative) & & \\
\hline Loneliness (Man away from Earth) & 2 & $1.25 \%$ \\
\hline Complexity (Mixed flames, flying letters) & 3 & $1.87 \%$ \\
\hline Grudge (Making an object fall on an enemy) & 1 & $0.6 \%$ \\
\hline Unhappiness (Man lying on the ground, weeping face) & 2 & $1.25 \%$ \\
\hline Desperation (Ball stuck in the dice) & 1 & $0.6 \%$ \\
\hline Concepts (positive) & & \\
\hline Peace (Yin and yang) & 1 & $0.6 \%$ \\
\hline Value of time (Watch) & 1 & $0.6 \%$ \\
\hline Time management (Watch) & 1 & $0.6 \%$ \\
\hline Justice/Equality (Scale, clock, bird & 5 & $3.12 \%$ \\
\hline Life (Birth, life, and death triangle) & 1 & $0.6 \%$ \\
\hline Freedom (Bird) & 3 & $1.87 \%$ \\
\hline Concepts (negative) & - & \\
\hline Future Plan (positive) & & \\
\hline Money (Coin) & 1 & $0.6 \%$ \\
\hline Dreams (Dreaming child) & 1 & $0.6 \%$ \\
\hline Future Plan (negative) & - & \\
\hline Religious Values (positive) & & \\
\hline Prayer (Prayer Rug, Mosque) & 3 & $1.87 \%$ \\
\hline Return to Islam (Ottoman Tughra) & 1 & $0.6 \%$ \\
\hline Interests (positive) & & \\
\hline Curiosity to learn (Book) & 1 & $0.6 \%$ \\
\hline Caricature & 1 & $0.6 \%$ \\
\hline Football (Child playing football) & 1 & $0.6 \%$ \\
\hline Electronics (Electrical circuits, $\mathrm{PC}$, tablet) & 2 & $1.25 \%$ \\
\hline Game & 1 & $0.6 \%$ \\
\hline Design (Logo) & 3 & $1.87 \%$ \\
\hline Sports (Team emblem, swimming, basketball) & 4 & $2.50 \%$ \\
\hline School (School logo) & 1 & $0.6 \%$ \\
\hline Parapsychology (Telekinesis) & 1 & $0.6 \%$ \\
\hline Traveling (Map) & 2 & $1.25 \%$ \\
\hline Interests (negative) & - & \\
\hline Personality (positive) & & \\
\hline Leadership (Führer, Alpha) & 2 & $1.25 \%$ \\
\hline Creativity (Bulb-burning in child's head) & 1 & $0.6 \%$ \\
\hline Chromaticity & 1 & $0.6 \%$ \\
\hline Combativeness (Ottoman Tughra) & 1 & $0.6 \%$ \\
\hline Helpfulness & 1 & $0.6 \%$ \\
\hline Orderliness & 1 & $0.6 \%$ \\
\hline Confident & 1 & $0.6 \%$ \\
\hline Sensitivity & 1 & $0.6 \%$ \\
\hline
\end{tabular}




\begin{tabular}{|c|c|c|}
\hline $\begin{array}{l}\text { Table } 5 \\
\text { Investigation of Adolescents' Statements about the Pictures They Drew to Explain Their Self-per } \\
\text { Gender Variable }\end{array}$ & & $n$ on the \\
\hline Adolescent Boys' Pictures Symbolizing Self-perception & $f$ & $\%$ \\
\hline Personality (negative) & & \\
\hline Dullness (Thinking, sleeping man) & 2 & $1.25 \%$ \\
\hline Indifference (Man with a hat on his head) & 1 & $0.6 \%$ \\
\hline Aggressiveness (Sword, being in front of the herd) & 3 & $1.87 \%$ \\
\hline Instability (Mixed letters, routes) & 1 & $0.6 \%$ \\
\hline Introversion (Box) & 1 & $0.6 \%$ \\
\hline Thoughtful (Thinking man) & 1 & $0.6 \%$ \\
\hline Adolescent Girls' Pictures Symbolizing Self-perception & & \\
\hline Emotions (positive) & & \\
\hline Hope (Butterfly, colorful trees) & 2 & $1.25 \%$ \\
\hline Happiness (Smiling boy, butterfly, snow, colored stripes, chocolate) & 9 & $5.62 \%$ \\
\hline Emotions (negative) & & \\
\hline $\begin{array}{l}\text { Complexity (One pale flower, question mark, crumpled paper, smiley and sad faces, complex } \\
\text { lines, a tree with a variety of fruit) }\end{array}$ & 11 & $6.87 \%$ \\
\hline Disconcerting (Weaving line) & 1 & $0.6 \%$ \\
\hline Pessimism (Circle with scribbles inside, dried tree, weeping girl, mixed lines) & 4 & $2.5 \%$ \\
\hline Unhappiness (Sad face, crying child, broken bottle, sun and clouds) & 10 & $6.25 \%$ \\
\hline Loneliness (Lone tree, sun, a vertical straight line, ball, lonely child, flower) & 5 & $3.12 \%$ \\
\hline Despair (Butterfly in cage, rail) & 2 & $1.25 \%$ \\
\hline Concepts (positive) & & \\
\hline Justice/Equality (Scale) & 3 & $1.87 \%$ \\
\hline Infinity (Infinity symbol) & 1 & $0.6 \%$ \\
\hline Freedom (Birds, sea, trees, sun, clouds) & 5 & $3.12 \%$ \\
\hline Life (Healthy children) & 1 & $0.6 \%$ \\
\hline Concepts (negative) & - & \\
\hline Future Plan (positive) & & \\
\hline Job (Doctor, teacher) & 2 & $1.25 \%$ \\
\hline Dreaming (Question mark, speech bubble) & 1 & $0.6 \%$ \\
\hline Interests (positive) & & \\
\hline Social Media (Google emblem) & 1 & $0.6 \%$ \\
\hline Football (Team emblem) & 1 & $0.6 \%$ \\
\hline Music (MP3) & 1 & $0.6 \%$ \\
\hline Fashion (Dress) & 1 & $0.6 \%$ \\
\hline Book & 1 & $0.6 \%$ \\
\hline Interests (negative) & & \\
\hline Mathematics & 1 & $0.6 \%$ \\
\hline Personality (positive) & & \\
\hline Differences (Note) & 1 & $0.6 \%$ \\
\hline Benevolence (Sun, clouds, birds, angel) & 3 & $1.87 \%$ \\
\hline Confident (Sun, sea, ship, princess, little girl, rain) & 6 & $3.74 \%$ \\
\hline Chrominance (Colorful lines, rainbow) & 2 & $1.25 \%$ \\
\hline Positivity (Trees, sun, smiling flower) & 2 & $1.25 \%$ \\
\hline Personality (negative) & & \\
\hline Introversion (Sad face, turtle, lonely child) & 3 & $1.87 \%$ \\
\hline
\end{tabular}




\section{Findings on the Statements of Self-perception through Emotions}

Some students drew their self-perceptions using positive emotions $(n=14)$, whereas others drew pictures expressing their negative emotions $(n=42)$.

Some explanations students gave about their drawings to express self-perception through their emotions are as follows:

“Happiness always helps people.” (Smiley)

"A young person whose spirit has become older because of the extreme shocks early in life and who hates his/her own past." (Sad face)

"I had a child in myself who was not liked and injured in the past; he was waiting for the future, hoping in the middle of the ocean." (Man lying on the ground in a corner of the room)

\section{Findings on the Expression of Self-perception through Various Concepts}

All students expressed their self-perception using at least one positive concept $(n=22)$.

Some of the statements related to figures drawn to express students' selfperception by means of various concepts are as follows:

"I am fair, I attach importance to time, and I am peaceful." (Scale, pigeon, watch)

"Being fair in life means behaving toward everyone equally and not discriminating against people. This scale represents me.” (Scale)

“Time and using time are very important to me."(Watch)

"Peace should prevail everywhere. I symbolize peace."(Yin and yang)

"I am as free as a bird." (Bird)

“A campsite represents me because I like to be free in nature." (Tent)

"The flag is freedom. I preferred to draw a flag as I felt myself free." (Flag) 


\section{Findings on the Expression of Self-perception through Interest Areas}

A majority of the students drew positive interest areas $(n=20)$; only one student drew a picture including a negative interest area $(n=1)$.

Some of the figure statements of the students expressing their self-perceptions through their interest areas are as follows:

"I like Photoshop very much." (PS logo)

"I am a traveler and would like to travel around the world." (World, plane)

"Travelling is the meaning of my life, and I like visiting different cities and countries." (Map)

"I am an athlete. I like sports." (Ball, basketball hoop)

\section{Findings on the Expression of Self-perception through Personality Characteristics}

Some students highlighted their positive characteristics $(n=23)$, whereas other students drew figures that highlighted their negative characteristics $(n=10)$.

Some of the statements made about the figures by students expressing their self-perception using personality characteristics are as follows:

"I always try to be at the forefront and the best." (Being at the front of the herd)

"The only person I look up to in my life is Führer." (F)

"This is an Alpha sign. Alpha means the leader of the herd, and I describe myself as the leader of a herd." (Alpha sign)

"I am an ambitious person, and I am happy with my ambitions." (Path, triangle)

"I can describe myself as an ambitious, fun, and approachable person."(Being in front of the herd) 
"This closed shining box represents me because people do not understand me without getting to know me and do not want to leave me after they get to know me." (Closed box)

\section{Findings on the Expression of Self-perception through Religious Values}

Among the students, four expressed self-perception with symbols including religious values:

"Prayer is the pillar of religion. Religion is paramount." (Prayer rug)

"I used this symbol because my life is based on prayer and religion."(Mosque)

\section{Discussion}

In this section, the results of the current research project are interpreted in the order of the sub-aims included in the introduction section above.

According to the results, the psychological well-being levels of the students were higher in female students. Additionally, the psychological well-being levels of adolescent girls who came from lower socioeconomic backgrounds and did not stay in the dormitories were higher. Many previous studies support this finding (Cenkseven, 2004; Cenkseven \& Akbaş, 2007; Gürel, 2009; Kuyumcu, 2012). However, there have been other studies showing that psychological well-being does not vary depending on gender (Hori, 2010; Kirkcoldy, Furnham, \& Siefen, 2010). In a similar vein, Kalafat (1996) concluded in his study that depression and happiness levels do not vary depending on gender.

The reason why there was no significant difference between psychological wellbeing and self-perception and why the girls had higher levels of psychological well-being scores than the boys might be justified by the fact that male participants in the study were all boarding students. In addition to staying in the dormitories, the fact that the schools were not mixed-sex schools might have negatively influenced boys' and girls' self-development and thus their psychological well-being. 
Qualitative findings of the study revealed that adolescents reflected selfperception mostly through figures expressing their negative emotions. From both Erickson's and Freud's perspectives, internal troubles and egocentric features (both characteristic of adolescence) may be reflected in the participants' psychological state. In a previous study, it was observed that many emotional, psychological, and behavioral problems and related stress factors appear during adolescence, and some methods were suggested to prevent this stress (Basut, 2006). In another study, socioeconomic problems, unemployment, university entrance, and education problems were cited as other issues that negatively affect adolescents' psychological development and mental health. One of the most important mental health problems experienced throughout this period is hopelessness. Difficulties encountered in the education process, unemployment, deprivation, and poverty are some of the other factors that can increase the level of hopelessness (Özmen, Dündar, Çetinkaya, Taşkın, \& Özmen, 2008).

Another important finding of the present study is that even though the girls' socioeconomic levels were lower, the psychological well-being levels of the adolescent girls that did not board at the school were higher than those of the boys, all of whom stayed in the dormitories. The issue of whether boarding at school has an influence on students' psychological well-being can be further studied in the future. Moreover, the effects of single-sex schools on the development of adolescents' self-perception and the relationship of students' positive/negative self-perception figures with their psychological well-being can also be a focus of future studies.

In addition, a significant positive or negative relationship between the participants' psychological well-being and the self-perception figures they drew was not found in this study. Nevertheless, according to similar previous studies, adolescents' self-perception levels have been identified as predictors of psychological well-being (Cenkseven, 2004; Gülaçt1, 2009; Gürel, 2009; Saygın, 2008; Schmutte \& Ryff, 1997; Segrin \& Taylor, 2007; Timur, 2008).

Much of the data in previous studies were collected using the picture drawing technique and obtained directly from the children (Dizman, Gültekin, \& Akyol, 2005; Miyandoab, 2008; Saydam, 2004; Şen, 2005). There have been no previous studies in which the perceptions and emotions of individuals during adolescence were investigated using this technique. Using the picture drawing 
technique applied in the present study, more detailed data can be collected about adolescents' perceptions, thoughts, and emotions. Therefore, it is recommended that drawings of different sample groups should be interpreted to help guidance personnel, counseling teachers, and experts working in this field in their processes of evaluating children and adolescents.

\section{References}

Basut, E. (2006). Stres, başa çıkma ve ergenlik. Çocuk ve Gençlik Ruh Sağ̆lğı Dergisi, 13(1), 31-36.

Cenkseven, F. (2004). Üniversite ögrrencilerinde öznel ve psikolojik iyi olmanın yordayıcılarının incelenmesi (Doctoral dissertation, Çukurova University, Adana, Turkey). Retrieved from https://tez.yok.gov.tr/UlusalTezMerkezi

Cenkseven, F., \& Akbaş, T. (2007). Üniversite öğrencilerinde öznel ve psikolojik iyi olmanın yordayıcılarının incelenmesi. Türk Psikolojik Damışma ve Rebberlik Dergisi, 3(27), 43-65.

Çınar, Ç. (2011). Lise son sinıf öğrencilerinin meslek seçimi kararlarında benlik algısının önemi (Master's thesis, Maltepe University, Istanbul, Turkey). Retrieved from https:// tez.yok.gov.tr/UlusalTezMerkezi

Cirhinlioğlu, F. G. (2006). Üniversite öğrencilerinde utanç eğilimi, dini yönelimler, benlik kurgular ve psikolojik iyilik hali arasindaki ilişkiler (Doctoral dissertation, Hacettepe University, Ankara, Turkey). Retrieved from https://tez.yok.gov.tr/UlusalTezMerkezi

Cooper, H., Okamura, L., \& McNeil, P. (1995). Situation and personality correlates of psychological well-being: Social activity and personal control. Journal of Research in Personality, 29, 395-417.

Corey, G. (2005). Psikolojik danısma, psikoterapi, kuram ve uygulamaları. Ankara: Mentis Yayınları.

Demir, H., Dereboy, F., \& Dereboy, Ç. (2009). Gençlerde kimlik bocalaması ve psikopatoloji. Türk Psikiyatri Dergisi, 20, 227-235.

Dizman, H., Gültekin, G., \& Akyol, A. (2005). Çocukları tanımada resimlerin önemi. Adli Psikiyatri Dergisi, 2(2), 23-30.

Erikson, E. H. (1968). Identity: Youth and crisis. New York, NY: W. W. Norton. 
Gülaçt1, F. (2009). Sosyal beceri eğitimine yönelik programın üniversite ögrencilerinin, sosyal beceri, öznel ve psikolojik iyi olma düzeylerine etkisi (Doctoral dissertation, Atatürk University, Erzurum, Turkey). Retrieved from https://tez.yok.gov.tr/UlusalTezMerkezi Gürel, A. N. (2009). Düşünme stilleri ve cinsiyetin psikolojik iyi olma hali üzerine etkileri (Master's thesis, METU, Ankara, Turkey). Retrieved from https://tez.yok.gov.tr/ UlusalTezMerkezi

Halisdemir, D. (2013). Üniversite ögrencilerinin psikolojik iyi oluşlar, kendini affetme düzeyleri ve geçmişe yönelik anne kabul red algıları arasındaki ilişkiler (Master's thesis, Gazi University, Ankara, Turkey). Retrieved from https://tez.yok.gov.tr/UlusalTezMerkezi

Hamurcu, H. (2011). Ergenlerin yetkinlik inançları ve psikolojik iyi oluşların yordamada psikolojik ibtiyaçlar (Doctoral dissertation, Selçuk University, Konya, Turkey). Retrieved from https://tez.yok.gov.tr/UlusalTezMerkezi

Haran, S. (1992). Ergenlerde gelişimsel kriz üzerine bir klinik örnek. Ankara Üniversitesi Psikiyatrik Kriz Uygulama ve Araștırma Merkezi Kriz Dergisi, 12(1), 47-53.

Hori, M. (2010). Gender differences and cultural contexts: Psychological well-being in cross-national perspective (Doctoral dissertation, Louisiana State University, Louisiana, U.S.A.). Retrieved from http://etd.1su.edu/docs/available/etd-04202010-122318/

Kalafat, S. (1996). Depresyon ve mutlulukta otomatik düşüncelerin rolü (Master's thesis, Ondokuz Mayıs University, Samsun, Turkey). Retrieved from https://tez.yok.gov.tr/ UlusalTezMerkezi

Karasar, N. (2007). Bilimsel araştırma yöntemi (17th ed.). Ankara: Nobel Yayınları.

Kirkcoldy, B., Furnham, A. F., \& Siefen, R. G. (2010). The effects of gender on physical and psychological well-being and life satisfaction among an adult population. International Journal of Child Health and Human Development, 3(3), 307-320

Köknel, Ö. (1982). Kaygıdan mutluluğa kişilik. İstanbul: Altın Kitaplar Yayınevi.

Kuyumcu, B. (2012). Üniversite ögrencilerinin duyguların fark etmeleri ve ifade etmeleri ile psikolojik iyi oluşları: Kültürlerarası bir karşılaştırma (Doctoral dissertation, Gazi University, Ankara, Turkey). Retrieved from https://tez.yok.gov.tr/UlusalTezMerkezi

Leech, N. L., \& Onwuegbuzie, A. J. (2007). An array of qualitative data analysis tools: A call for data analysis triangulation. School Psychology Quarterly, 22, 557-584.

Miyandoab, S. H. (2008). Zibinsel engelli kardeşi olan ve zibinsel engelli kardeşi olmayan 7-13 yaş grubu çocukların aile resim çizimlerinin karşılaştırılması ve analizi (Doctoral dissertation, Hacettepe University, Ankara, Turkey). Retrieved from https://tez.yok. gov.tr/UlusalTezMerkezi 
Myers, J. E., Sweneey, T. J., \& Witner, J. M. (2004). İyilik hali/wellness çalı̧̧ma kitabı (trans. F. Korkut). Ankara: Anı Yayıncilik.

Özmen, D., Dündar, P. E., Çetinkaya, A. Ç., Taşkın, O., \& Özmen, E. (2008). Lise öğrencilerinde umutsuzluk ve umutsuzluk düzeyini etkileyen etkenler. Anadolu Psikiyatri Dergisi, 9, 8-15.

Ryff, C. D. (1989). Happiness is everything, or is it? Explorations on the meaning of psychological well-being. Journal of Personality and Social Psychology, 57(6), 1069-1081.

Ryff, C. D. (1991). Possible selves in adulthood and old age: A tale of shifting horizons. Psychology and Aging, 6(2), 286-295.

Ryff, C. D. (1995). Psychological well-being in adult life. Current Directions in Psychological Science, 4(4), 99-106.

Ryff, C. D., Lee, Y. H., Essex, M. J., \& Schmutte, P. S. (1994). My children and me: Midlife evaluations of grown children and self. Psychology and Aging, 9(195)-205.

Saydam, R. B. (2004). Çocuk çizimlerinin klinik değerlendirmedeki yeri. Yansıtma, Psikopatoloji ve Projektif Testler Dergisi, 1(1-2), 111-124.

Saygın, Y. (2008). Üniversite öğrencilerinin sosyal destek, benlik saygısı ve öznel iyi oluş düzeylerinin incelenmesi (Master's thesis, Selçuk University, Konya, Turkey). Retrieved from https://tez.yok.gov.tr/UlusalTezMerkezi

Schmutte, P. S., \& Ryff, C. D. (1997). Personality and well-being: reexamining methods and meanings. Journal of Personality and Social Psychology, 73(3), 549-559.

Segrin, C., \& Taylor, M. (2007). Positive interpersonal relationships mediate the association between social skills and psychological well-being. Personality and Individual Differences, 4(43), 637-646.

Şen, D. (2005). Çocuklarda hastaneye yatma etkilerinin projektif yöntem olan resim çizme yoluyla incelenmesi (Master's thesis, Ege University, Izmir, Turkey). Retrieved from https://tez.yok.gov.tr/UlusalTezMerkezi

Timur, M. S. (2008). Boşanma sürecinde olan ve olmayan evli bireylerin iyi oluş düzeylerini etkileyen faktörlerin incelenmesi (Master's thesis, Ankara University, Ankara, Turkey). Retrieved from https://tez.yok.gov.tr/UlusalTezMerkezi

Yıldırım, A., \& Şimşek, H. (2013). Sosyal bilimlerde nitel araştırma yöntemleri (9th ed.). Ankara: Seçkin Yayıncılık.

Y1lmaz, M. F. (2013). Üniversite öğrencilerinin psikolojik iyi oluşlarının problemli internet kullanımı ve bazı demografik özellikler açısından incelenmesi (Master's thesis, Anadolu University, Eskisehir, Turkey). Retrieved from https://tez.yok.gov.tr/UlusalTezMerkezi 